\title{
ZIRCON FACIES IN THE PALEOCENE-EOCENE ORCA GROUP INDICATE A PROVENANCE LINK TO THE CHUGACH TERRANCE, PRINCE WILLIAM SOUND, ALASKA
}

WILL SPARKHAWK FISHER, Union College

Research Advisor: John Garver

\section{INTRODUCTION}

Much of the southern Alaska continental margin is made up of marine sedimentary rocks and distinct terranes that have been deposited and accreted from the Cretaceous to the present (Plafker et al., 1994). The Upper Cretaceous to Eocene Chugach-Prince William (CPW) terrane is interpreted to be one of the thickest accretionary complexes in the world, and it is bounded to the north by the Border Ranges fault and Wrangellia composite terrane (Garver and Davidson, 2015). The CPW terrane is inferred to be the Mesozoic accretionary complex of southern Alaska (Amato et al., 2013), but alternate hypotheses suggest it originally formed far to the south (Cowan, 2003). The CPW consists of inboard mesomélange (the McHugh Complex \& Potter Creek Assemblage) and stratigraphically younger outboard flysch facies (the Valdez \& Orca groups) and associated volcanics (Plafker et al., 1989; Garver and Davidson, 2015; Amato et al., 2013). The blueschist to greenschist Potter Creek Assemblage formed in Cretaceous-Early Jurassic subduction (Amato et al., 2013). The McHugh Complex is made up of mélange and deformed conglomerates and sandstones and ages range from the Jurassic to mid Cretaceous (Amato et al., 2013). The majority of the CPW terrane ( $>90 \%)$ is comprised of the outboard flysch facies of the Late Cretaceous to Eocene Valdez and Orca groups juxtaposed along the Contact fault system (Garver and Davidson, 2015, Dumoulin, 1987; Fig. 1). The CPW terrane was intruded by the 61-50 Ma Sanak-Baranof belt (SBB) near-trench plutons that are diachronous (Bradley et al., 2003; Cowan, 2003). There are two predominant hypotheses concerning the intrusion of these plutons and the amalgamation and translation of the CPW terrane. The Baranof-Leech River hypothesis suggests the CPW terrane formed to the south and was then translated along the margin (Cowan, 2003). A more northern hypothesis where CPW terrane formed in situ and the Resurrection Plate subducted underneath it (Haeussler et al., 2003). These alternate hypotheses each require a different sediment provenance for the CPW terrane outboard flysch assemblages.

The goal of this study is to determine the depositional age, provenance, and original tectonic setting of the flysch facies of CPW terrane, with an emphasis on the younger Orca Group. Using maximum depositional ages (MDA) and the KS test, we delineate four distinctive zircon facies: 1) Miners Bay ( 61-59 Ma, $\mathrm{n}=2244$ grains); 2) Sawmill (59-55 Ma, $\mathrm{n}=1340)$; 3) Hawkins (55-50 Ma, n=1914); and 4) Montague (52-31 Ma, n=1144) (Fig. 2). A major stratigraphic conundrum is that the oldest Orca is age-correlative and has a similar provenance to the youngest Valdez Group at 61-60 Ma, and the location of these rocks casts doubt of models that rely on the Contact fault system as a terrane-bounding fault.

\section{BACKGROUND \& GEOLOGICAL SETTING}

\section{The Valdez Group}

The Campanian-Paleocene Valdez Group consists of thick, deformed turbidites with minor tholeiitic basalts (Plafker et al., 1989; Davidson and Garver, 2017; Gross Almonte et al., 2019). The sedimentary and volcanic rocks of the Valdez Group were 


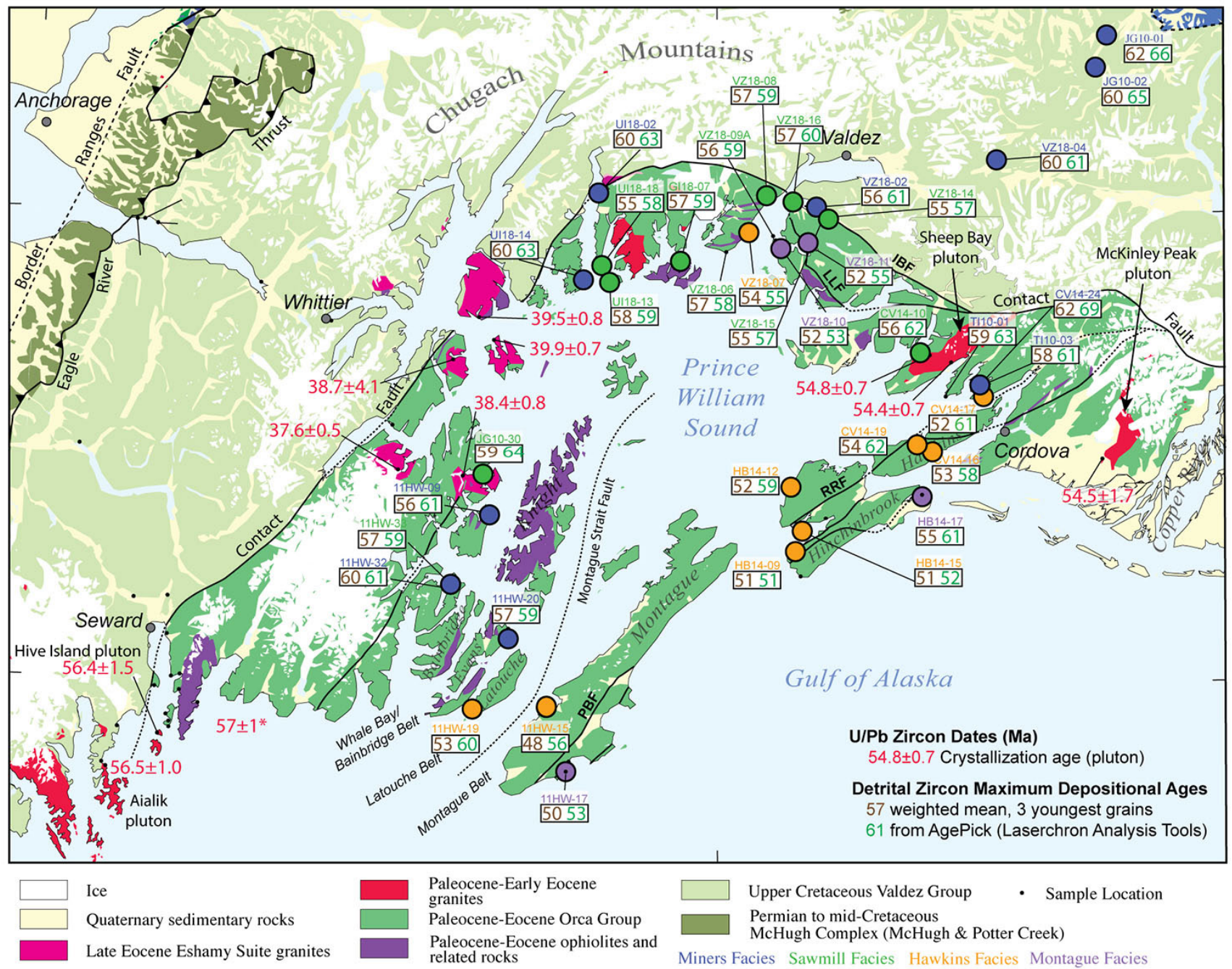

Figure 1: Geologic map of Prince William Sound showing sample locations used in this study. The inboard Valdez Group is juxtaposed against the outboard Orca Group across the Contact fault system. (Figure modified from Wilson et al., 2015).

originally defined by Schrader (1900) and Grant and Higgins (1910). Regionally the Valdez Group is metamorphosed to lower greenschist facies (Plafker et al., 1989, Dusel-Bacon, 1991). The Valdez Group is primarily comprised of medium-grained sandstones, locally with biotite, muscovite and intermittently veined shales (Grant and Higgins, 1910). Traditionally the age has been interpreted to be Campanian to Maastrichtian based on a few widely dispersed fossils (Jones and Clark, 1973).

\section{The Orca Group}

The Orca Group consists of a thick $(6-10 \mathrm{~km})$ sequence of marine turbidites well-exposed extending in Prince William Sound (PWS), and west to Kodiak (Fig. 2; Plafker et al., 1994). This belt makes up the Prince William terrane, and it is juxtaposed by the Contact fault system to the adjacent Valdez Group
(Chugach terrane) to the north (Tysdal and Case, 1979). The Orca Group was defined as consisting of thick-bedded, gray- to brown-weathering sandstones, with black limestones, arkoses, interbedded with typically thin layers of dark shale and slate, and minor conglomerates (Schrader, 1900; Grant and Higgins, 1910). The Orca Group is interpreted to have a lower metamorphic grade (zeolite - prehnite pumpellyite) (Schrader, 1900; Dusel-Bacon). The Orca Group is in depositional contact with ophiolitic rocks of Knight Island, Resurrection Peninsula, and Glacier Island (Tysdal and Case, 1977; Wilson and Hults, 2012; Davidson and Garver, 2017; Noseworthy et al., 2019). The occurrence of foraminifers in rocks of eastern Prince William Sound, Hinchinbrook Island, Porcupine Point, and Hawkins Island indicate a probable age range of Paleocene to early and middle Eocene (Plafker et al., 1985). U-Pb geochronology 
of detrital zircon in these rocks partly reaffirms early paleontological studies (Davidson and Garver, 2017).

\section{The Contact Fault}

The Geology of PWS has a complicated history in the literature that largely revolves around the relationship between the Valdez and Orca Groups. The two dominant rock groups in PWS, the Orca and Valdez Groups, were essentially given de facto group status in 1910 (Grant and Higgins). A metamorphic break was initially described, and interpreted as an angular unconformity with the younger Orca resting unconformably on the older Valdez; however, it was also proposed that perhaps the units were in fault contact (i.e. Capps and Johnson, 1915; but see discussion in Moffit, 1954). By the 1970s, it was commonly accepted that there is a series of faults juxtaposing the inboard Valdez Group to the north against the outboard Orca Group to the south. Plafker et al. (1977) formally defined these faults as the Contact fault system. Upon further examination, it became evident that the Contact fault system is comprised of multiple fault segments, some with complex dextral strike-slip fault histories (Bol and Roeske, 1993), but its significance as a terrane boundary was less clear because the units are commonly indistinguishable in the field (Domoulin, 1987; Bol and Gibbons, 1992; Malik et al., 2019). These concerns leave two fundamental questions about the Contact fault: are the Orca and Valdez Groups a depositional continuum potentially with an unconformity or are the Orca and Valdez Groups from two distinct source terranes that have been placed next to each other along the Contact fault.

\section{METHODS}

$\mathrm{U}-\mathrm{Pb}$ detrital zircon ages were obtained from samples taken along several transects across the Contact fault in northern PWS (this study; Malik et al., 2019) and along the Richardson Highway (Gross Almonte et al., 2019). In addition, Pope et al. (2019) focused on conglomerates of the Orca. Coarse-grained sandstones were sampled for detrital zircon U-Pb dating at the University of Arizona LaserChron Center. Zircons were extracted from the rock sample using standard rock pulverization techniques, followed by density separation. In this study 100 or 300 zircons were randomly selected and individually dated using LAICP-MS to determine grain-age populations. Shale samples were taken from representative locations in northern PWS for major and trace element analysis at the Hamilton Analytical Labortory at Hamilton College. The goal of sampling different blocks of Orca Group shale is to ascertain whether there are geochemically distinct tectonic blocks within the Orca Group (Fig. 3). For detrital zircon work the maximum depositional age (MDA) was calculated using the weighted mean of the three youngest grains in a sample and using AgePick (Laserchron Analysis Tools). Probability density functions (PDFs) are used to show grain-age distributions. Using maximum depositional ages (MDA), the KS test, and PDFs, I define four distinct zircon facies in the Orca Group (Fig. 2). To understand the significance of the sediment contribution from the adjacent Chugach terrane, a synthetic DZ signal was made from the Valdez Group ( $\mathrm{n}=3354)$, McHugh Complex $(\mathrm{n}=$ 916), and Potter Creek assemblage $(n=874)$, the three primary elements of the Chugach terrane (Fig. 4; Amato and Pelvis, 2010, Amato et al., 2013). These composites were used in a three-component model to estimate the maximum sediment contribution (MSC) of the Chugach terrane to the Orca. The MSC was modeled by taking the maximum component of Valdez at $72 \mathrm{Ma}$, the age of the primary population in the Valdez Group.

\section{RESULTS}

Combining our new U-Pb MDAs from northern PWS with previously published results (Davidson and Garver, 2017), the timing of deposition of the Orca Group is at least 61.5-31.0 Ma or younger in Prince William Sound. There are four distinctive MDA defined KS-supported facies within the Orca Group. The Miners facies ( 61-59 Ma) consists of a primary $71 \mathrm{Ma}$ population and secondary $108 \mathrm{Ma}$ population (Fig. 2). The Sawmill (59-55 Ma) facies is characterized by a primary population at $59 \mathrm{Ma}$ and secondary $108 \mathrm{Ma}$ population and a significant decrease in Precambrian grains (Fig. 2). The Hawkins facies has three primary populations at 62,71 , and 88 Ma with a minor secondary grain-age population at $121 \mathrm{Ma}$ (Fig. 2). The Hawkins facies is the only facies 


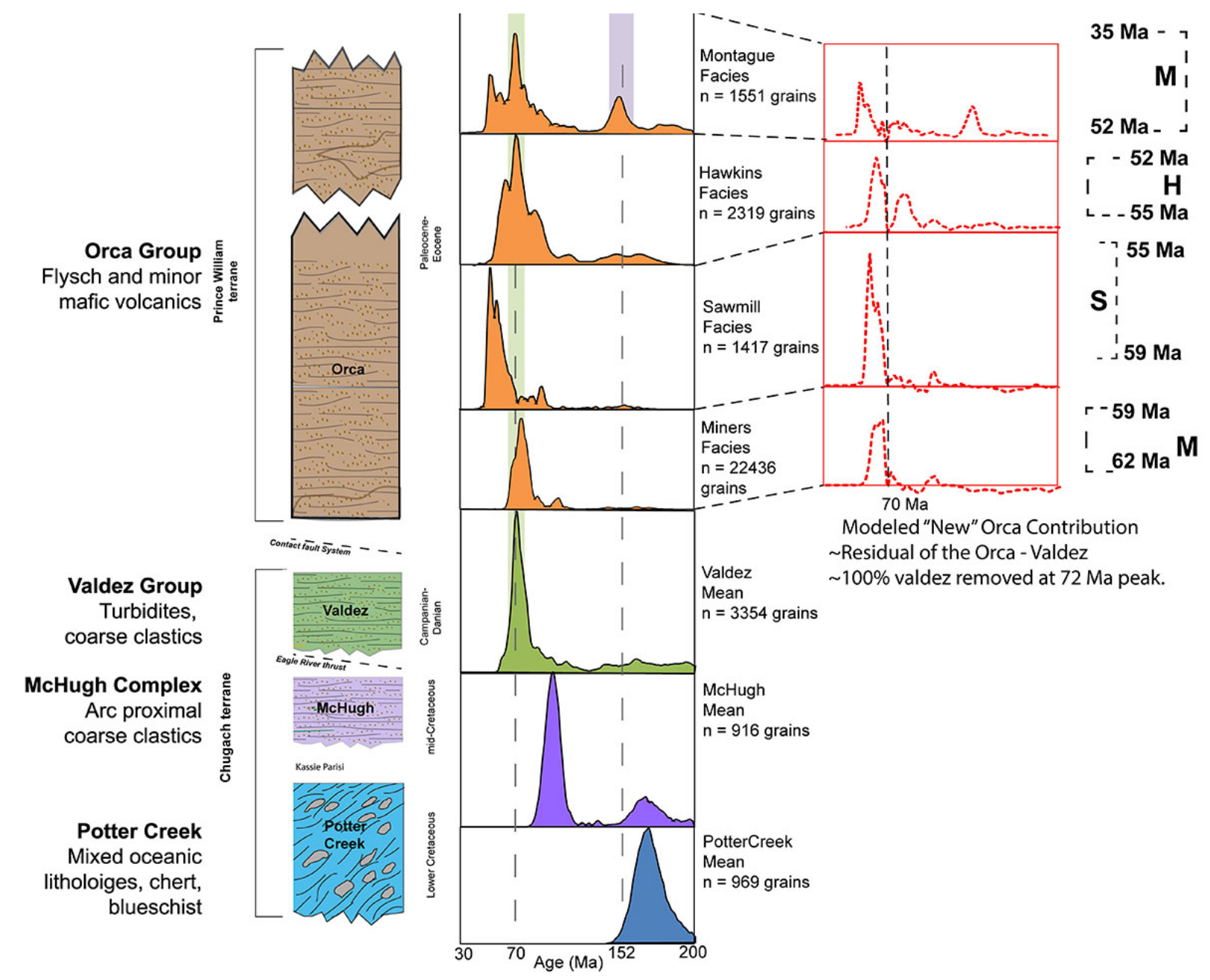

Figure 2: Stratigraphic column for the Chugach-Prince William terrane and correlative composite probability density functions $(n=\#$ of zircon grains). Black dashed time bins (Upper right) represent MDA time bins for the Orca Group facies. Pottercreek and McHugh zircon data from Amato and Pavlis, 2010 and Amato et al., 2013. Red dashed line graphs are the residual PDF with the Chugach MSC removed in each Orca Group zircon facies (see text).

recording a primary $88 \mathrm{Ma}$ grain-age population. The young Montague facies (58-50 Ma) has a primary grain-age population at notably 53 and 73 Ma with a secondary grain age population at $152 \mathrm{Ma}$ (Fig. $2)$. The source of the Orca Group was probably a Paleocene arc ( $61-50 \mathrm{Ma})$ built on a Cretaceous and Jurassic metaplutonic basement along with significant sediment contribution from the Valdez Group (84$61 \mathrm{Ma}$ ). This relationship is substantiated by near identical shale geochemistry across the Orca and Valdez groups (Fig. 3).

The maximum sediment contribution (MSC) into the Orca basin from the adjacent Chugach terrane may be represented by three possible units: 1) Potter Creek Assemblage; 2) McHugh Complex; and 3) Valdez Group. If any unit contributed significant zircon to the Orca basin, it would be the Valdez Group because it is regionally extensive and it dominates in volume. Modeling the MSC of the Valdez Group into the Orca Group shows that the Miners facies could have received as much as $\sim 88 \%$ of its zircon from the Valdez Group. The Sawmill facies received the smallest MSC of the Valdez Group accounting for only up to $\sim 35 \%$ of its sediment. The Hawkins facies MSC of the Valdez Group could have been up to $\sim 55 \%$ derived from the Valdez Group. Similarly, the Montague facies, the most outboard facies, the MSC was as much as $\sim 55 \%$. The Potter Creek, and McHugh, with distinctive JK populations, cannot have been a significant sediment source in the Orca Group. They were found to be $<1 \%$ in the modeled Orca Group zircon facies, and this result may suggest the Eagle River thrust is a significant terrane bounding structure and that these units were not present in the source region. 


\section{DISCUSSION}

The zircon facies of the Orca Group show a changing provenance over time and the maximum sediment contribution model suggests a depositional setting in close proximity to the Valdez Group. The Valdez Group and the Orca Group have similar zircon facies and sedimentary provenance. The Orca Group can be modeled as containing a maximum of $\sim 35-85 \%$ zircon recycled from the Valdez-or identical source. The Orca Group has clasts of the Valdez Group (Pope et al., 2019), which means there must have been some erosion of the Valdez Group.

How can depositional models incorporate rocks of practically the same age (60-61 Ma) with differing degrees of metamorphism, but similar provenances?

A possible model for the deposition of the Orca Group and similarly aged, but metamorphosed Valdez Group is to underplate and quickly exhume Valdez Group rocks in an accretionary wedge complex with the exhumed Valdez Group rocks supplying the majority of the sediment for the Orca Group. This exhumation may have dominated the sediment supply $(>50 \%)$ of the Orca Group with the exception of the Sawmill facies. Note that deposition of the Sawmill facies was synchronous with ophiolite emplacement and intrusion of the SBB plutons in PWS (Davidson and Garver, 2017); perhaps this magmatism temporarily rearranged drainage systems and diluted the Valdez Group signal.

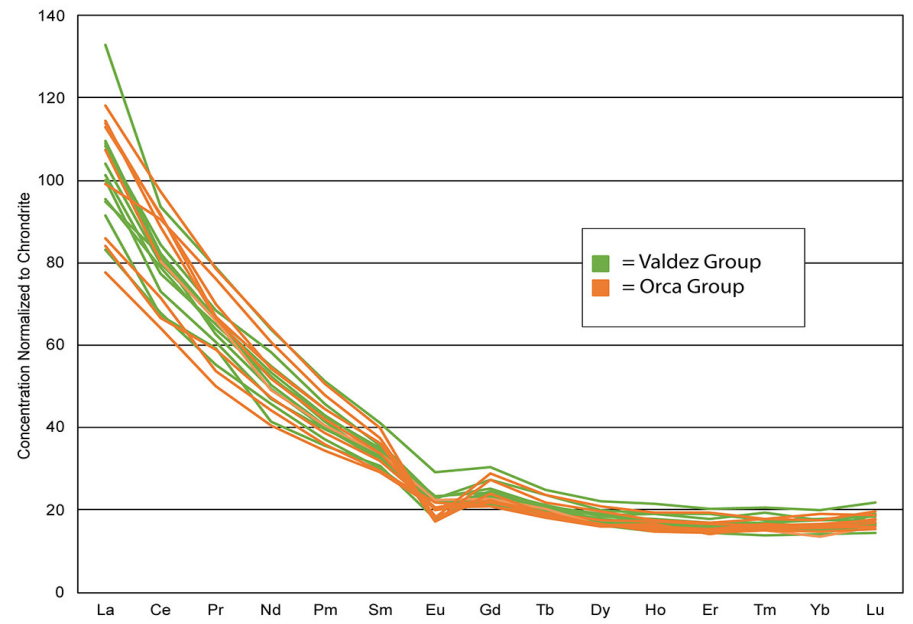

Figure 3: Rare Earth Element concentrations of shale samples from the Orca (orange, $n=9$ ) and Valdez (green, $n=11$ ) Groups. Normalized to chondrite compositions of McDonough and Sun (1995).

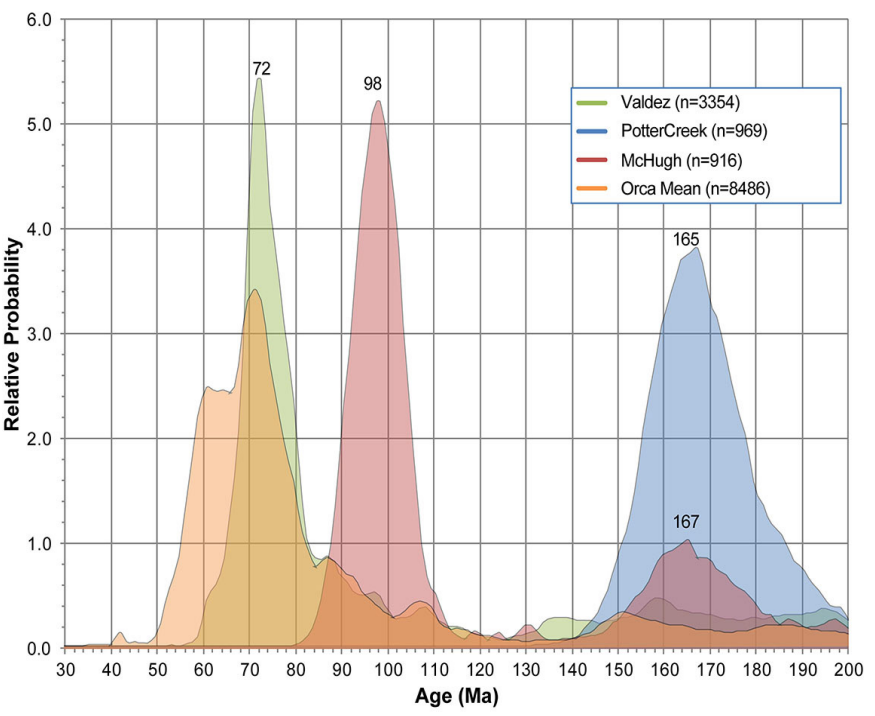

Figure 4: Probability density functions of the three main sandstonebearing petrotectonic assemblages of the Chugach terrane: Valdez Group $(n=3354)$, McHugh Complex $(n=916)$, and the Pottercreek Assemblage $(n=874)$. McHugh and Potter Creek data from Amato and Pavlis (2010) and Amato et al. (2013).

The Hawkins and Montague facies have similar components, but reflect more complicated mixing. The Hawkins facies in particular records a "new" 88 Ma sediment flux only seen from 55-52 Ma, and the Montague facies records a 53 Ma grain-age population perhaps indicating a short-lived arc rejuvenation.

Because volcanic clasts dominate the lithic types in the Valdez and Orca Groups, the source terrane was likely an arc environment (Dumoulin, 1987). The similarities in sediment composition between the Valdez and the Orca Groups would suggest a single source terrane that evolved over time (Dumoulin, 1987). Likewise, the shale geochemistry of rocks across the Contact fault system in northern PWS have almost identical rare earth element abundances in the Valdez and Orca Groups.

One proposed source region for the Orca and Valdez Group is the Coast Mountains Plutonic Complex (CMPC) (Hollister, 1982, Farmer, et al., 1993). The CMPC is a $1700 \mathrm{~km}$ long belt of Jurassic to Paleogene plutonic rocks located to the south of the current location of the Orca and Valdez Groups (Farmer, et al., 1993; Cecil et al., 2011). Metamorphism and subsequent exhumation suggests rapid uplift of the CMPC (up to $30 \mathrm{~km}$ ) occurred between 62$48 \mathrm{Ma}$ producing up to $3 \times 105 \mathrm{~km} 3$ clastic during the Paleocene and Eocene, when the Orca Group 
was being deposited (Hollister, 1982). The CMPC also experienced crustal thickening from $85-58 \mathrm{Ma}$ followed by a period of transtension from 58-50 Ma resulting in decompression and crustal thinning (Hollister and Andronicos, 2006).

Zircon facies within the Orca Group may allow for the depocenter to be determined. There are two possible situations in which the Valdez and Orca became juxtaposed. The Valdez Group could have been stitched to the Orca Group and traveled along the margin eroding into the Orca group. Alternatively, the Valdez Group could have been in its modern position by $\sim 61 \mathrm{Ma}$ and each Orca Group zircon facies represents slivers tapping into different source terranes. The Miners and Sawmill facies could be dominated by detritus from erosion of the Valdez Group or material from the original source. The MSC residuals show that the Montague and Hawkins facies are unique and distinct from one another and show a new source rock entered the basin (Fig. 2). The Montague facies may represent the position of the Orca Group depocenter farthest away from the south.

\section{CONCLUSIONS}

The provenance of the Orca and Valdez Groups is a fundamental element for understanding the geologic framework in southern Alaska. Previous petrographic studies (Dumoulin,1987), structural analyses (Bol and Gibbons, 1992), and this study of detrital zircon grain-age populations and shale geochemistry suggest that the Contact fault system is not a terrane bounding fault. Our modeling suggests that Chugach-supplied sediment in the Orca Group may be as high as 75$88 \%$, and this result implies that significant recycling of the Valdez Group into the Orca Group occurred from 62-52 Ma. If the Orca and Valdez Groups originated in the south, thickening of the CMPC could have supplied the Valdez Group and rapid exhumation could have continued to supply sediments to the Orca Group. The difference in metamorphic grade between the Valdez and Orca Groups could be explained by rapid underplating, exhumation and erosion of greenschist facies rocks of the Valdez Group. Thus, the similarities between the units suggest the Valdez and Orca groups are not separate terranes rather the depositional continuum of each other from a common source terrane. The relationship of the PotterCreek and McHugh to Valdez is unclear, but these facies do not appear in the Orca Group (if recycled), indicating the Eagle River thrust could be a major terrane bounding fault. The Chugach terrane in this model is a composite terrane and may best be viewed as Potter Creek + McHugh as separate from the Valdez and Orca Groups which are similar, but with differing degrees of metamorphism.

\section{ACKNOWLEDGEMENTS}

I would like to thank Dr. John Garver for all of his support, thoughtful advice, and always trying to look at the problem a new way. I would also like to thank Dr. Cameron Davidson for all of his patience, handwork, and support. I would like to acknowledge our field team: Mollie Pope, Nicholas Gross-Almonte, Victor Garcia, Caitlin Noseworthy, and Alysala Malik. I would like to recognize Alysala Malik and Nicholas Gross-Almonte for their mineral separation work and the Carleton College Geology Department for SEM work. This material is based upon work supported by the Keck Geology Consortium and the National Science Foundation under Grant No. 1659322. The field work was made possible by: NSF EAR 1728013 (Garver); NSF EAR 1727991 (Davidson). U-Pb geochronology work was supported by the Arizona LaserChron Center, run by George Gehrels and Mark Pecha.

\section{REFERENCES}

Amato, J.M. and Pavlis, T.L., 2010. Detrital zircon ages from the Chugach terrane, southern Alaska, reveal multiple episodes of accretion and erosion in a subduction complex. Geology, 38(5), pp.459462.

Amato, J.M., Pavlis, T.L., Clift, P.D., Kochelek, E.J., Hecker, J.P., Worthman, C.M. and Day, E.M., 2013. Architecture of the Chugach accretionary complex as revealed by detrital zircon ages and lithologic variations: Evidence for Mesozoic subduction erosion in south-central Alaska. Bulletin, 125(11-12), pp.1891-1911.

Bol, A.J., Coe, R.S., Grommé, C.S. and Hillhouse, 
J.W., 1992. Paleomagnetism of the Resurrection Peninsula, Alaska: Implications for the tectonics of southern Alaska and the Kula-Farallon ridge. Journal of Geophysical Research: Solid Earth, 97(B12), pp.17213-17232.

Bol, A.J. and Gibbons, H., 1992. Tectonic implications of out-of-sequence faults in an accretionary prism, Prince William Sound, Alaska. Tectonics, 11(6), pp.1288-1300.

Bol, A.J. and Roeske, S.M., 1993. Strike-slip faulting and block rotation along the Contact fault system, eastern Prince William Sound, Alaska. Tectonics, 12(1), pp.49-62.

Bradley, D.C., Kusly, T.M., Haeussler, P.J., Goldfarb, R.J., Miller, M.L., Dumoulinf, J.A., Nelson, S.W. \& Karl, S. M., 2003, Geologic signature of early Tertiary rifge subduction in Alaska: Geology of transpressional orogen developed during ridgetrench interaction along the North Pacific margin: Geological Society of America Special Paper, v. 371, p. 19-49.

Cecil, M.R., Gehrels, G., Ducea, M.N. and Patchett, P.J., 2011. U-Pb-Hf characterization of the central Coast Mountains batholith: Implications for petrogenesis and crustal architecture. Lithosphere, 3(4), pp.247-260.

Cowan, D.S., 2003. Revisiting the Baranof-Leech River hypothesis for early Tertiary coastwise transport of the Chugach-Prince William terrane. Earth and Planetary Science Letters, 213(3-4), pp.463-475.

Davidson, C. and Garver, J.I., 2017. Age and origin of the resurrection ophiolite and associated Turbidites of the Chugach-Prince William terrane, Kenai peninsula, Alaska. The Journal of Geology, 125(6), pp.681-700.

Dumoulin, J.A., 1987. Sandstone composition of the Valdez and Orca Groups, Prince William Sound, Alaska (No. 1774). US Government Printing Office. P. 1-34.

Dusel-Bacon, C. E., Metamorphic history of Alaska, in The Geology of North America, vol. G-1, The Geology of Alaska, edited by G. Plafker and H. C. Berg, pp. 495-533, Geol. Soc. Am., Boulder, Colo., 1994.

Farmer, G.L., Ayuso, R. and Plafker, G., 1993. A Coast Mountains provenance for the Valdez and Orca groups, southern Alaska, based on $\mathrm{Nd}, \mathrm{Sr}$, and $\mathrm{Pb}$ isotopic evidence. Earth and Planetary Science Letters, 116(1-4), pp.9-21.

Grant, U.S. and Higgins, D.F., 1910. Reconnaissance of the geology and mineral resources of Prince William Sound Alaska. Washington: Government Printing Office. P. 22-32.

Garver, J.I., Davidson, C. and Northfield, M.N., 2012. Tectonic evolution of the. Chugach-Prince William terrane in Prince William Sound and Kodiak Island, Alaska. In Proceedings from the 25th Keck Geology Consortium Undergraduate Research Symposium, Amherst (pp. 1-7).

Garver, J.I. and Davidson, C.M., 2015. Southwestern Laurentian zircons in upper Cretaceous flysch of the Chugach-Prince William terrane in Alaska. American Journal of Science, 315(6), pp.537556.

Gross Alamonte, N., Fisher, W.S., Malik, A.M., Garver, J.I., and Davidson, C.M. 2019. Age and provenance of the Upper Cretaceous to Paleocene Valdez Group of the Chugach terrane from the Richardson Highway and northern Prince William Sound, Alaska. Geological Society of America Abstracts with Program, Cordilleran Section - 115th Annual Meeting, Portland Oregon. v. 51, n. 4. doi: 10.1130/ abs/2019CD-329673.

Haeussler, P.J., Bradley, D.C., Wells, R.E. and Miller, M.L., 2003. Life and death of the Resurrection plate: Evidence for its existence and subduction in the northeastern Pacific in Paleocene-Eocenetime. Geological Society of AmericaBulletin, 115(7), pp.867-880.

Hollister, L.S., 1982. Metamorphic Evidence For Rapid (2 mm/yr) Uplift of A Portion 
of the Central Gneiss Complex, COAST

MOUNTAINS,BC. Canadian Mineralogist, 20, pp.319-332.

Hollister, L.S. and Andronicos, C.L., 2006. Formation of new continental crust in Western British Columbia during transpression and transtension. Earth and Planetary Science Letters, 249(1-2), pp.29-38.

McDonough, W.F. and Sun, S.S., 1995, The Composition of the Earth; Chemical Geology, v. 120, p. 223-253.

Malik, A.M., Fisher, W.S., Gross Alamonte, N., Garver, J.I., Davidson, C.M., 2019. U-Pb dating of detrital zircon from turbidites of the Chugach and Prince William terrane in Prince William Sound, Alaska: Implications of the significance of the Contact fault system as a terrane boundary. Geological Society of America Abstracts with Program, Cordilleran Section - 115th Annual Meeting, Portland Oregon. v. 51, n. 4. doi: 10.1130/abs/2019CD-32939.

Plafker, G., Jones, D.L. and Pessagno Jr, E.A., 1977. A Cretaceous accretionary flysch and melange terrane along the Gulf of Alaska margin. The United States Geological Survey in Alaska: Accomplishments during, pp.B41-B43.

Plafker, G., Nokleberg, W.J. and Lull, J.S., 1989. Bedrock geology and tectonic evolution of the Wrangellia, Peninsular, and Chugach terranes along the Trans-Alaska Crustal Transect in the Chugach Mountains and southern Copper River Basin, Alaska. Journal of Geophysical Research: Solid Earth, 94(B4), pp.4255-4295

Plafker, George, and Berg, H.C., 1994, Introduction, in Plafker, George, and Berg, H.C., eds., The Geology of Alaska: Geological Society of America, p. 1-16.

Pope, Mollie, Fisher, Will S., Malik, Alysala M., Garver, John I. and Davidson, Cameron, 2019. Provenance of Sandstone Clasts From Conglomerate of the Paleocene-Eocene Orca Group in Prince William Sound, Alaska. The
Geological Society of America: Cordilleran Section.

Schrader, F.C., 1900, A reconnaissance of a part of Prince William Sound and the Copper River district, Alaska, in 1898: U.S. Geological Survey Annual Report, 20, pt. 7, p. 341-423.

Tysdal, R.G. and Case, J.E., 1979. Geologic map of the Seward and Blying Sound quadrangles, Alaska (No. 1150), p. 9-12

Wilson, F.H., Hults, C.P., Mull, C.G, and Karl, S.M, comps., 2015, Geologic map of Alaska: U.S. Geological Survey Scientific Investigations Map 3340, pamphlet 196 p., 2 sheets, scale 1:1,584,000, http://dx.doi.org/10.3133/sim3340. 